\title{
A ditadura militar e o metalúrgico: o discurso autoritário na ficha do DEOPS*
}

Francis Lampoglia**

\begin{abstract}
Resumo: Esse trabalho estuda o funcionamento discursivo de um trecho da ficha do DEOPS (Departamento de Ordem Política e Social) coletado do Arquivo Público do Estado de São Paulo, que inscreve efeitos de sentidos sobre a greve dos metalúrgicos do $\mathrm{ABC}$ paulista. A análise preliminar dos dados aponta que, na voz do policial que redigiu o documento, é inscrito um espaço de arquivo e memória, deixando entrever a formação discursiva ao qual o(s) sujeito(s) se filia $(\mathrm{m})$, aquela que condena os sujeitos metalúrgicos.
\end{abstract}

Palavras-chave: ditadura militar; greve dos metalúrgicos; arquivo discursivo.

\section{Introdução}

Nosso trabalho estudou o discurso de documentos produzidos durante a ditadura militar brasileira, mobilizando a fundamentação teórica a Análise do Discurso de matriz francesa de Michel Pêcheux para flagrar as marcas ideológicas de dizeres naturalizados sobre a censura.

\section{A Análise do Discurso}

A Análise do Discurso (AD) de linha francesa, fundada por Michel Pêcheux em 1969, possui mecanismos teóricos que permitem a observação da construção do discurso e de seu funcionamento. Dentre eles, destacamos a noção de memória discursiva, que constitui num conjunto de dizeres proferidos anteriormente ao momento do discurso. Segundo Orlandi (2005), a memória discursiva é "o saber discursivo que torna possível todo dizer e que retorna sob a forma do pré-construído, o já dito que está na base do dizível, sustentando cada tomada da palavra" (Ibid. op. cit., p. 31). Esse conceito não é, entretanto, um aglomerado homogêneo de dizeres, mas "é necessariamente um espaço móvel de divisões, de disjunções, de deslocamentos e de retomadas, de conflitos de regularização... Um espaço de desdobramentos, polêmicas e contra-discursos" (PÊCHEUX, 1999, p. 56), sendo passível de atualização face aos acontecimentos.

Atrelado à noção de memória, o arquivo discursivo constitui num conjunto de dizeres referentes a um determinado tema. Para Pêcheux (1994), o arquivo discursivo pode ser "entendido no sentido amplo de "campo de documentos pertinentes e disponíveis sobre uma questão" (Ibid. p. 57). Os documentos

\footnotetext{
* Esse texto é um recorte do TCC "Documentos da/sobre a ditadura militar brasileira: silenciamento e esquecimento de dizeres" (2009).

** Mestranda do Programa de Pós-Graduação em Ciência, Tecnologia e Sociedade da UFSCar. Bolsista FAPESP. Pesquisadora do E-L@DIS - Laboratório Discursivo: sujeito, rede eletrônica e sentidos em movimento, da FFCLRP/USP. E-mail: francidusp@hotmail.com
} 
mencionados por Pêcheux referem-se ao agrupamento de dizeres retomados do/no interdiscurso, configurando no repertório, na base que sustenta a memória e viabiliza a leitura e o dizer.

Ao conceber o arquivo no campo do discurso, promovemos uma reflexão sobre o modo como foi construído o documento, quais ideologias que influenciaram sua elaboração, quais os sentidos que as palavras adquiriram e adquirem conforme o contexto em que o leitor está inserido, que memórias são ativadas ao percorrer o texto, enfim, uma discussão que permite o estudo sob a ótica discursiva sobre a ficha do DEOPS.

\section{Análise da ficha do DEOPS}

O fim dos anos de 1970 e início da década de 1980 foram marcados por diferentes manifestações populares, dentre elas destacamos as greves dos metalúrgicos do ABC paulista. Desse momento histórico, coletamos a ficha criminal abaixo, retirado do fundo DEOPS e pertencente ao Arquivo Público do Estado de São Paulo.

\section{gogtivo da Dissmatoe

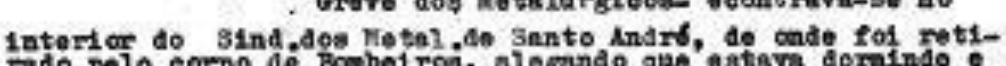

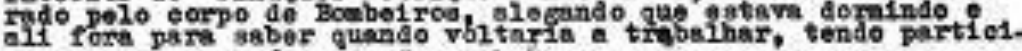 pedo des Aaserblécia de Jagetube.}

Neste recorte, percebe-se o uso do discurso relatado, em que um sujeito fala em lugar de outro, permitindo a visualização da assimetria de vozes, poderes e de lugares de autoridade. O sujeito, com voz de autoridade, cala o outro e impõe o seu discurso, posicionando e significando o outro de acordo com a formação ideológica do sujeito-policial. Este sujeito não permite a voz do metalúrgico, a não ser citada pela autoridade policial. Ao fazer uso do discurso relato, o sujeito policial empregou o verbo "alegar" no trecho "de onde foi retirado pelo corpo de Bombeiros, alegando que estava dormindo", em que o uso desse verbo remete ao sentido de dúvida sobre esse "dormir", desautorizando o dizer do sujeito-indiciado e colocando-o numa posição de descrédito, de que sua fala não é digna de confiança.

Percebe-se que a dúvida semeada pelo sujeito-policial emerge no verbo alegar e confirma-se no trecho "tendo participado", remetendo ao sentido de que, embora o sujeito-indiciado se esforce a ocupar a posição de inocente, seu ato do passado - a participação das Assembléias - o coloca na posição de culpado. Nota-se aqui que memória discursiva é atualizada no momento em que são referidos fatos não compartilhados pelos sujeitos no presente momento da produção do enunciado, mas anteriormente a ele. O plural de Assembléia - grafado com inicial maiúscula - remete às várias assembléias ocorridas em Jaçatuba em prol da luta operária, o que já constitui um motivo para a detenção do sujeito indiciado. Com isso, observa-se também que tal enunciado pertence a um determinado arquivo discursivo, qual seja, a das assembléias/manifestos/reuniões de oposição à ditadura militar, em que a participação 
do sujeito-acusado numa dessas manifestações constituía numa afronta ao poder daquele momento estabelecido, contribuindo como um agravante para o julgamento do sujeito.

\section{Considerações finais}

Diante do exposto, verifica-se a necessidade de se ter acesso ao contexto sócio-histórico-ideológico para poder interpretar os sentidos inscritos nas materialidades discursivas, no caso, uma ficha do Deops. Desse modo, é possível verificar que o dizer é fundamentado pela memória discursiva, em que as diferentes formas de leitura dependem do arquivo discursivo ao qual o sujeito tem acesso.

\section{Referências}

ARQUIVO Público do Estado de São Paulo. Centro de Arquivo Permanente. Acervo Deops: normas e práticas de acesso. São Paulo, 2009b. Disponível em: <http://www.arquivoestado.sp.gov.br/deopsnormas1.php.> Acesso em: 02.jul.2009.

ORLANDI, Eni P. Análise de discurso: princípios \& procedimentos. Campinas, SP: Pontes, 2005.

PÊCHEUX, M. Papel da memória. In: ACHARD, Pierre [et.al.]. Papel da memória. Campinas, SP: Pontes, 1999. p. 49-57.

. Ler o arquivo hoje. In.: ORLANDI, E. (org.). Gestos de leitura: da história

no discurso. Campinas, SP: Unicamp, 1994. 